\title{
Studying Part-Time at University: From Research to Policy to Practice
}

\author{
DAVID A. KEAST
}

University of Alberta

\section{ABSTRACT}

In the last few years universities in Canada have seen a noticeable decline in part-time enrollments. This trend has given rise to a number of pressing concerns regarding the needs and aspirations of part-time students and the status and future of part-time study. Unfortunately, these concerns exist against a backdrop of relatively little research on parttime university students, programs, and attendance which is useful for decisions on policy and practice. This paper highlights the results of research which examined part-time programming at Canadian universities and the needs and characteristics of undergraduate student populations with potential for part-time degree completion. It is argued that the mature, working, part-time learner constitutes a distinct nontraditional group, with a distinct set of educational needs and expectations. The findings suggest changes which may be necessary in university functioning in order to better serve these student populations in the future. Results are compared with other recent research and implications for institutional policy and practice are discussed. 


\section{RÉSUMÉ}

Comme les contraintes économiques dans le secteur post-secondaire deviennent une préoccupation permanente, il se manifeste une appréciation de la contribution des étudiants à temps partiel dans les universités, et une sensibilisation de leurs besoins. Ces derniers temps, les universités canadiennes ont néanmoins enregistré un déclin perceptible des inscriptions à temps partiel, ce qui inquiète les milieux universitaires. Malheureusement, cette inquiétude se présente sur une toile de fond d'un nombre restreint de recherches au sujet des étudiants d'université à temps partiel, des programmes, et de la présence aux cours, toutes des informations utiles pour prendre des décisions en matière de règlements et de pratique. Le présent article souligne les résultats de la recherche qui s'intéresse aux programmes d'études à temps partiel des universités canadiennes et aux besoins et caractéristiques des populations d'étudiants au premier cycle potentiellement aptes à obtenir un diplôme à temps partiel. Il est soutenu que les apprenants à temps partiel, matures et détenteurs d'un emploi constituent un groupe distinct, non traditionnel, avec des besoins et des attentes distincts en matière d'éducation. Les résultats suggèrent des changements qui, à l'avenir, seront peut-être nécessaires au fonctionnement des universités pour mieux servir ces populations d'étudiants. Ces résultats sont comparés avec d'autres recherches effectuées récemment et des implications concernant la réglementation et les pratiques institutionnelles sont aussi examinées.

\section{INTRODUCTION}

The question of part-time university attendance is fraught with a number of difficulties, both conceptual and pragmatic. On the conceptual side, we are faced with the problem of defining exactly what a parttime student is. The answers to this question are varied, at times can be nationally, regionally, and even institutionally specific, and can include distinctions between daytime and evening students, on- and off-campus students, degree-seeking and non-degree-seeking students, or university students and those attending other types of institutions. Within each of these distinctions are further considerations of age, gender, marital and 
employment status, and income and prior education, which tend to complicate our understanding of the needs and goals of these student groups (see Roche, Shale, \& Kelley, 1996, for a breakdown of part-time student definitions). On the practical side, we face the recurring issue of how to design effective programming for these groups. Part of the problem here has been our neglect of the prior conceptual issues related to "who" these groups are, and therefore a failure to precisely identify the range of educational needs and services which would be required to deliver effective programs. Unlike the case of younger, full-time undergraduates, part-time learners are diverse and difficult to identify; they vary widely on characteristics and needs; and they present institutions with a number of unfamiliar challenges. Programs, if they are to be successful, must be targeted to quite specifically defined student markets. Herein lies one fundamental distinction between traditional and nontraditional approaches to a university education. Many conventional mode research universities continue to concentrate on traditional delivery (essentially, opening doors in September to a "captive audience"), and this policy contrasts sharply with the need to understand nontraditional students and to respond with appropriate programming. Fortunately, many of the important conceptual issues and most of the practical issues related to nontraditional learning can be at least partially addressed through empirical research. Unfortunately, at present, very little research exists on part-time university attendance, particularly in Canada, but in other countries as well. The lack of "comprehensive data on the central issues arising from part-time study" was recognized by Devlin (1989, p. 30), and in the U.K., Bourner, Reynolds, Hamed, and Barnett (1991) suggest that "compared to full-time higher education, the information available on part-time higher education is very limited" (p. 1). In the U.S., noted scholars including Astin (1993), and Pascarella and Terenzini (1991, 1998) identify the need for new research programs and increased knowledge and understanding of the mature, part-time student and the problems of nontraditional learning. This knowledge will be necessary in order to remain "in-step" with the rapidly changing profile of undergraduate students. Indeed, Terenzini (1996) refers to the study of the effects of postsecondary education on groups such as "part-time students, 
adults, and returning students" as an "empirical black hole" (p. 8), and goes on to state, "despite the clear demographic trends confronting our colleges and universities, ... little research has been done on the educational outcomes for nontraditional student groups" (p. 9). Overall, the lack of useful knowledge and information which could guide decision making reinforces the need for comprehensive study of part-time student populations and programs.

This paper highlights the results of survey research which examined part-time programming at Canadian universities and the needs and characteristics of undergraduate student populations with potential for parttime degree completion. In a general sense, the research attempted to respond to a number of questions relating to: (a) the demographic, socioeconomic, and educational profiles of potential part-time students; (b) the main reasons for part-time attendance; (c) the extent of and need for evening and weekend programming; and (d) students' educational needs and expectations for service provision and degree completion. Attempts were also made to construct a picture of part-time degree programming across the nation. The findings suggest changes which may be necessary in university functioning in order to better serve these student populations in the future. Results are compared with other recent research and implications for institutional policy, practice, and future research are discussed.

\section{BACKGROUND}

Of the research that exists on part-time university education in Canada, noteworthy is an historical review conducted by Belanger, Lynd, and Mouelhi (1982) which documented part-time university enrollments over a 40 year period from 1939 to 1979. In 1939, part-time students comprised $14 \%$ of all university students; in 1964, $26 \%$ of the university population was enrolled part-time; and by 1979, part-time enrollments had risen to $38 \%$. More recent national data on student enrollments in postsecondary education indicate that until very recently, these figures have remained relatively constant (see Devlin, 1989). In $1990-91,62 \%$ of university students were enrolled full-time, with $38 \%$ studying part-time (Department of the Secretary of State of Canada, 1992). By 1992-93, these figures had shifted slightly to $64 \%$ of students 
studying full-time and 36\% studying part-time in Canada's universities (Human Resources Development Canada, 1994).

Belanger et al. (1982) suggest that the increase in part-time enrollments from approximately 1954 to 1979 was due to increases in participation by older students ( 20 to 40 year olds), and particularly the growth in participation by women. Women outnumbered men in the part-time student population in the 1940s and continue to do so. Indeed, participation by women in higher education in Canada during the 1992-93 academic year was significant; $52 \%$ of full-time enrollment and $62 \%$ of part-time enrollment (Human Resources Development Canada, 1994). Data also show that the age of the part-time student population is increasing. By 1984, 64\% of part-timers were 30 years old or older. By 1990 , the proportion of part-time undergraduate university students 25 years of age or older had reached $75 \%$, with more than $50 \%$ being 30 years of age or older (Secretary of State of Canada, 1992). More recent data suggest that this trend may continue (Human Resources Development Canada, 1994).

Given this enrollment background, some within the higher education community predicted declining enrollments among the traditional student body (full-time 18 to 24 year olds) and continued growth in the part-time student sector, with the distinct possibility that part-time students would become "tomorrow's majority" on university campuses (see Belanger et al., 1982; Bertrand, cited in Anisef, 1989). Similarly, based on research in the U.K., Bourner et al. (1991) predicted that "if current trends continue, at some time in the 1990s the part-timers will constitute a majority of those in higher education" (p. 3). In Canada, recent enrollment numbers have not, of course, supported such predictions. In the last few years universities in most provinces across the country have seen a noticeable drop in part-time enrollments. For the fall of 1994, the Atlantic provinces experienced an average 10 to $12 \%$ decrease in part-time undergraduate enrollments, Quebec approximately a 6\% decrease, Ontario almost an $8 \%$ decrease, with variations in the western provinces ranging from increases of $4 \%$ to a decrease of $14 \%$ (Association of Universities and Colleges of Canada, 1994). For 1995, the proportion of university students enrolled part-time in member institutions of the Association of Universities and 
Colleges of Canada (AUCC) had dropped to $32 \%$. Preliminary enrollment data for 1996 showed a continued overall decline of two percentage points to $30 \%$ (Association of Universities and Colleges of Canada, 1996a).

Research in the U.S. on undergraduate students has been considerably more extensive than elsewhere, but even here, attention has focused almost exclusively on the effects of college on the younger, full-time student, with very little attention paid to the educational experiences of nontraditional learners. At the same time, the changing demographic and socioeconomic profile of the typical U.S. college undergraduate has been well documented and discussed (see Altbach, 1998; Astin, 1998; and Pascarella \& Terenzini, 1998). Indeed, Pascarella and Terenzini (1998) admit that "the knowledge base for How College Affects Students permitted us to draw conclusions about a population of students that no longer dominates American postsecondary education" (p. 152). For example, in the decade from 1984 to 1994, the number of white undergraduates increased by $5 \%$, while the number of non-white undergraduates increased by $61 \%$. By 1993 , more than $40 \%$ of U.S. undergraduates were 25 years old or older, and by 1996, approximately $43 \%$ of all undergraduates were attending college on a part-time basis. Further, substantial numbers of full-time students also hold jobs. In the U.S., it is estimated that in 1993, $46 \%$ of all full-time, 18 to 24 year-old college students were employed, and that more than half of these students were working at least 20 hours a week (Pascarella \& Terenzini, 1998).

Perhaps most alarming overall are the employment trends among both younger full-time students and mature part-timers. In addition to U.S. figures, recent national data in Canada (Canadian Education Statistics Council, 1996) suggest that increasing numbers of full-time students are seeking employment to pay for education, and our own research (Keast \& Broadbent, 1997) clearly showed the vast majority of part-timers as being employed. Other research (Etcheverry, Clifton, \& Roberts, 1993; Johnson, 1994) suggests that at larger universities, employment levels for younger full-time students may be higher than the U.S. norm, especially for those students who tend to withdraw (see Johnson, 1994). 
In short, evidence suggests that our traditional conception of a university entrance student - the young, 18 to 24 year-old high school graduate, financed primarily by parents, and headed for full-time attendance - may no longer be viable. This traditional "educational reality" may no longer exist. If that is true, then institutions will be forced to respond with fundamental changes in policy and practice which are more aligned with the needs of new and diverse student groups. This shift means becoming clear on which questions are important to ask, and how to go about answering them effectively. The discussion which follows is intended to address at least some of these questions, to raise important issues for part-time students and nontraditional learning, and to stimulate and encourage further dialogue on this topic.

\section{DESIGN AND METHOD}

Four related populations served as a basis for questionnaire surveying procedures, which, in turn, were initiated in four stages: (a) Canadian universities (1995-96 AUCC member institutions), (b) part-time undergraduate students at the University of Alberta, (c) university transfer students at Grant MacEwan Community College, Edmonton, Alberta, and (d) non-returning University of Alberta Faculty of Arts students eligible for readmission within the last 10 years. The main intent of this research design was to place the knowledge gained from three populations of potential part-time students into the larger context of part-time degree offerings at universities across the nation.

The characteristics of each population warranted the design and pilottesting of four separate survey instruments. The development of survey instruments was based on a review of relevant literature and previous research, on feedback from a statistics consultant and survey designer, and on input provided by two informed colleagues. Questionnaires were then reassessed and refined by a research team in the Special Sessions office at the University of Alberta. The questionnaire to AUCC member institutions was subjected to a trial run within the University of Alberta's academic and administrative system. For French language institutions, a copy of the survey instrument was prepared in French by an experienced 
translator. Each of the other survey instruments were pilot-tested using a small group of respondents from the respective populations being studied. The results of this multi-stage feedback process exhausted modifications made to the questionnaires.

All surveying procedures were conducted between January and April of 1996. For the first stage, 88 AUCC member institutions were surveyed (not including the Ontario Institute for Studies in Education and, at the time, Royal Roads Military College). In all, 62 questionnaires were returned, and after the removal of 3 distance education universities, a response group of 59 institutions was created with a final return rate of approximately $76 \%$. Surveying procedures for part-time undergraduates involved a computer-generated random sample drawn from the academic records system at the University of Alberta. For former Arts students, questionnaires were distributed to all students with current local-area addresses based on data provided by the Faculty of Arts at the University of Alberta. Students in these two groups were sent a packet containing a cover letter, the questionnaire, a postage-paid return envelope, and an identification card which could be used for non-respondent tracking. Final response rates for part-time undergraduates and former Faculty of Arts students were $63 \%$ and $49 \%$ respectively, after exclusion of unusable returns. For students at Grant MacEwan College, data were collected through the administration of in-class surveys based on a stratified sample (by year and program area) of the university transfer population. Table 1 provides more detail on samples, unusable returns, response rates, and percentages for each population surveyed.

Because of the distinct methods used for each sample, four separate data sets were created. All coding of questionnaires, tracking of respondents and non-respondents, and computer entry of data were conducted by a co-researcher, or by Special Sessions staff under the direct supervision of the co-researcher and the principal researcher. Open-ended responses (Canadian universities and University of Alberta part-time undergraduates only) were content-analyzed by both the principal researcher and co-researcher, and agreement was reached on a categorization scheme. These data were then coded and entered into respective data sets consistent with other variables analyzed. 


\section{SUMMARY OF FINDINGS ${ }^{1}$}

\section{Canadian Universities}

Responses from AUCC member institutions were examined in four major categories of variables including (a) background information, (b) part-time degree programs including program administration, (c) evening and weekend course offerings including the administration of courses, and (d) services for part-time students.

Fifteen institutions ( $25.4 \%$ of respondents) indicated offering specific undergraduate degree programs (distinct from regular programs) which could be completed entirely on a part-time basis. The range of programs reported was diverse, however, for those with evening course offerings, the most frequent programs fell into the arts and commerce/business areas, followed by applied arts, nursing, social work, and science respectively. For weekend course offerings, applied arts and business management were the most frequently specified areas, however, the range of programs and institutions in which weekend courses were offered was considerably smaller than for evening offerings. (For a model displaying part-time degrees in Canada and other variables which interact with decisions to study part-time see Keast, 1998.) The majority of part-time programs (14 out of 15) were administered by regular academic departments rather than by separate administrative units or continuing education units.

Enrollment data were collected which permitted comparison of part-time to total undergraduate attendance. When these enrollment proportions were examined, roughly $80 \%$ of respondent institutions were above the $10 \%$ mark in part-time to total undergraduate enrollments, with almost $50 \%$ of institutions at or above the $20 \%$ mark. Twenty percent of institutions fell below the $10 \%$ mark. The mean for part-time to total undergraduate enrollments in degree credit programming was $23.03 \%(S D=15.86)$, a figure somewhat more conservative than that reported by other sources (see Belanger et al., 1982; Devlin, 1989; and Human Resources Development Canada, 1994. Readers should bear in mind that proportions reported by these sources often appear to be more global, including undergraduates and graduates, credit and noncredit 
Figure 1

Part-time to Total Undergraduate Enrollment — Canadian Universities

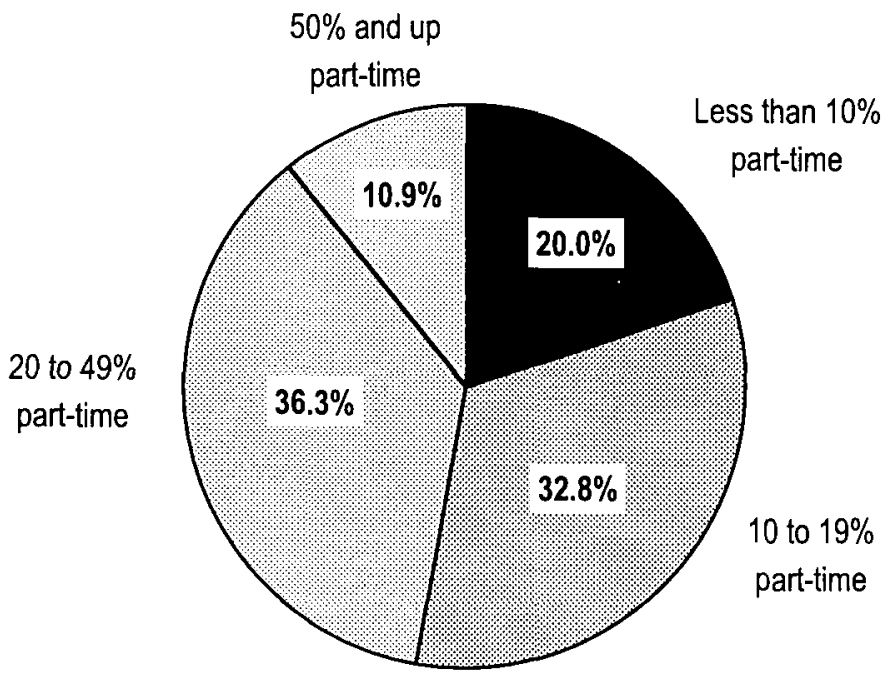

programming, and other sectors within postsecondary education. This is itself an issue in need of greater clarification and precision.). Figure 1 displays the proportion of part-time to total undergraduate enrollments for responding institutions.

All institutions were asked a series of questions which explored the extent of evening and weekend credit courses offered, faculties offering the greatest number of evening and weekend courses, and the administration of these courses. The mean number of evening courses offered by all respondents was $204.19(S D=217.71)$, while the mean number of weekend courses was $7.53(S D=9.81){ }^{2}$ Overall, 47 institutions indicated offering evening credit courses, while only 17 institutions offered weekend courses. The most frequently indicated faculties offering evening credit courses were arts, education, and commerce respectively. When overall frequencies were examined for weekend programming, this ranking shifted to education, arts, and commerce respectively. For the majority of respondents $(66.7 \%)$, evening and weekend course offerings were administered by regular academic departments. 
A final set of questions solicited data on the type and extent of services offered to part-time students. Roughly $44 \%$ of responding institutions published materials specifically for part-time students and almost one-half $(47.5 \%)$ provided some form of financial support for this group. For the majority of institutions, full-time and part-time application deadlines at four points in the academic year (first term, second term, spring, and summer sessions) were the same. Only 10 institutions (17.2\%) indicated the existence of formal policy on extended office hours for teaching faculty; the remainder indicating no formal policy, an informal approach, or that they were uncertain. Other university services with extended hours (although, in some cases, not exclusively for part-time students) included libraries, bookstores, registrars' offices, continuing education units, counselling offices, recreation services, food services, career and placement offices, and a part-time studies office.

\section{Student Response Groups}

Data on the needs and characteristics of undergraduate student respondents including part-time undergraduates at the University of Alberta, university transfer students at Grant MacEwan Community College, and former University of Alberta Faculty of Arts students, were examined in six major categories of variables: (a) personal backgrounds, (b) academic backgrounds, (c) finances and employment, (d) educational expectations and student services, (e) technology and the alternative delivery of courses, and ( $f$ ) advantages and disadvantages of part-time attendance. Findings from each data set to some extent revealed distinctive student profiles, however, analyses also revealed certain commonalities in backgrounds, characteristics, and expectations.

In all three response groups, females outnumbered males almost two to one. The majority of part-time undergraduate and former Faculty of Arts respondents at the University of Alberta were 25 years of age and over $(75.8 \%$ and $74.6 \%$ respectively) with significant percentages 30 and over $(56.7 \%$ and $53.4 \%$ respectively). These findings are roughly consistent with participation patterns in postsecondary education at the national level (Human Resources Development Canada, 1994. See also discussions in the first section of this paper). The majority were married 
(60.2\% and $60.9 \%$ respectively), but with no or few dependent children, and large percentages $(84.3 \%$ and $51.3 \%$ respectively) indicated some level of postsecondary education prior to enrollment at the University of Alberta. In contrast, the mean age for university transfer students at Grant MacEwan College was at least 10 years below that of other groups, at 21.20 years $(S D=4.63)$. The vast majority were single and full-time students. Their highest level of education prior to Grant MacEwan enrollment was predominantly high school. Tables 2 and 3 provide a breakdown by gender and age categories for the three response groups, and Table 4 shows the highest level of education prior to students' enrollment at the time of the study.

For part-time undergraduates at the University of Alberta, the most frequently mentioned reason for studying part-time was the desire to work while attending classes. Other reasons for attending part-time included personal and family responsibilities, and the need to work to cover expenses. At the same time, close to $60 \%$ of part-time undergraduates at the University of Alberta expected to complete their degrees, and almost $68 \%$ of these respondents indicated part-time status for their next registration. Eighty percent of Grant MacEwan students intended to complete degrees at the University of Alberta, but almost all planned to attend full-time. Much smaller numbers of former Faculty of Arts students $(24.3 \%)$ had plans for degree completion. For this group, the main reasons given for not completing degrees included attendance at another institution, lack of interest, employment, and personal and family responsibilities. Table 5 displays data on expectations for degree completion for the three groups of respondents.

Large numbers of part-time undergraduates $(77.6 \%)$ and former Faculty of Arts students (84.3\%) at the University of Alberta were employed either full-time or part-time. In contrast, roughly half of Grant MacEwan students held part-time jobs. The majority of part-time undergraduates and former Arts students had family incomes of $\$ 30,000$ per year and up (63.7\% and $64.9 \%$ respectively). In each of these groups, almost $30 \%$ had incomes of $\$ 60,000$ per year and up. Table 6 provides data on employment status for the three response groups. 
Table 2

Gender Comparisons - Three Student Groups

\begin{tabular}{|c|c|c|c|c|c|c|}
\hline & \multicolumn{2}{|c|}{$\begin{array}{l}\text { Part-time U of A } \\
\quad(N=275)\end{array}$} & \multicolumn{2}{|c|}{$\begin{array}{l}\text { Grant McEwan } \\
(N=221)\end{array}$} & \multicolumn{2}{|c|}{$\begin{array}{l}\text { Former Faculty of Arts } \\
\qquad(N=320)\end{array}$} \\
\hline & $f$ & $\% f$ & $\vec{f}$ & $\% f$ & $f$ & $\% f$ \\
\hline Male & 97 & 35.3 & 87 & 39.4 & 106 & 33.1 \\
\hline Female & 178 & 64.7 & 134 & 60.6 & 214 & 66.9 \\
\hline
\end{tabular}

Table 3

Age Comparisons - Three Student Groups

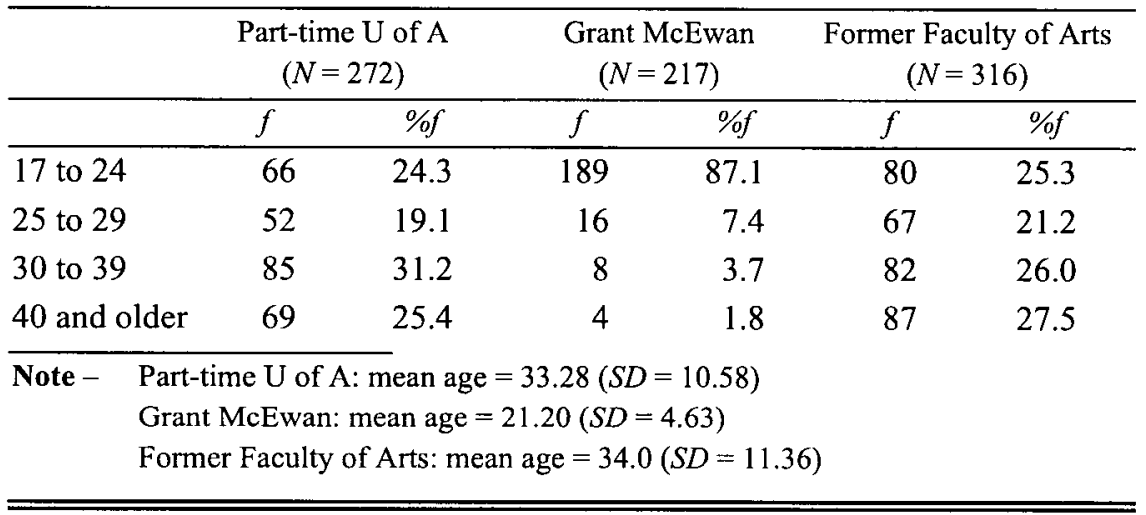

Table 4

Prior Education Comparisons - Three Student Groups

\begin{tabular}{|c|c|c|c|c|c|c|}
\hline & \multicolumn{2}{|c|}{$\begin{array}{l}\text { Part-time } \mathrm{U} \text { of A } \\
\qquad(N=275)\end{array}$} & \multicolumn{2}{|c|}{$\begin{array}{c}\text { Grant McEwan } \\
(N=222)\end{array}$} & \multicolumn{2}{|c|}{$\begin{array}{c}\text { Former Faculty } \\
\text { of Arts } \\
(N=319)\end{array}$} \\
\hline & $f$ & $\% f$ & $f$ & $\% f$ & $f$ & $\% f$ \\
\hline Grade 10 or higher & 4 & 1.5 & 2 & 0.9 & 10 & 3.1 \\
\hline High School & 39 & 14.2 & 157 & 70.7 & 145 & 45.5 \\
\hline Some college & 18 & 6.5 & 15 & 6.8 & 33 & 10.4 \\
\hline Completed college & 42 & 15.3 & 15 & 6.8 & 51 & 16.0 \\
\hline Some university & 66 & 24.0 & 33 & 14.8 & 62 & 19.4 \\
\hline Undergraduate degree & 74 & 26.9 & --- & --- & 13 & 4.1 \\
\hline Some graduate level & 14 & 5.1 & $\cdots$ & --- & 3 & 0.9 \\
\hline Graduate degree & 18 & 6.5 & --- & --- & 2 & 0.6 \\
\hline
\end{tabular}


Table 5

Expectations for Degree Completion - Three Student Groups

\begin{tabular}{lcrrrrr}
\hline & \multicolumn{2}{c}{$\begin{array}{c}\text { Part-time U of A } \\
(N=267)\end{array}$} & \multicolumn{2}{c}{$\begin{array}{c}\text { Grant McEwan } \\
(N=221)\end{array}$} & \multicolumn{2}{c}{$\begin{array}{c}\text { Former Faculty of Arts } \\
(N=317)\end{array}$} \\
\hline & \multicolumn{1}{c}{$f$} & \multicolumn{1}{c}{$\% f$} & \multicolumn{1}{c}{$f$} & $\% f$ & \multicolumn{1}{c}{$f$} & $\% f$ \\
\hline Yes & 160 & 59.9 & 177 & 80.1 & 77 & 24.3 \\
No & 16 & 6.0 & 18 & 8.1 & 138 & 43.5 \\
Uncertain & 23 & 8.6 & 26 & 11.8 & 102 & 32.2 \\
Other & 68 & 25.5 & --- & --- & --- & ---
\end{tabular}

Note - The "Other" catgory includes those not registered in specific programs and those completing their last courses.

Table 6

Employment Status - Three Student Groups

\begin{tabular}{|c|c|c|c|c|c|c|}
\hline & \multicolumn{2}{|c|}{$\begin{array}{l}\text { Part-time U of A } \\
\qquad(N=272)\end{array}$} & \multicolumn{2}{|c|}{$\begin{array}{l}\text { Grant McEwan } \\
(N=218)\end{array}$} & \multicolumn{2}{|c|}{$\begin{array}{l}\text { Former Faculty of Arts } \\
\qquad(N=318)\end{array}$} \\
\hline & $f$ & $\% f$ & $f$ & $\% f$ & $f$ & $\% f$ \\
\hline Full-Time & 131 & 48.2 & 10 & 4.6 & 204 & 64.2 \\
\hline Part-Time & 80 & 29.4 & 109 & 50.0 & 64 & 20.1 \\
\hline Not employed & 53 & 19.5 & 94 & 43.1 & 42 & 13.2 \\
\hline Other & 8 & 2.9 & 5 & 2.3 & 8 & 2.5 \\
\hline
\end{tabular}

Despite differences in profiles, attendance plans, and expectations for degree completion, large numbers of students from all three response groups indicated "somewhat likely, very likely, or yes, would attend" on the likelihood of attendance in evening and weekend degree completion programming. Figure 2 shows the distribution of these responses for the three groups. Overall, responses by all three groups on the need for afterhours access to student services included the registrar's office, faculty offices, department offices, counselling services, and parking services. By far, the most preferred time for access to such services was 4:30 p.m to $6: 30 \mathrm{p} . \mathrm{m}$. weeknights. 
Figure 2

\section{Likelihood of Attendance in Evening and Weekend Programs}



The data above include only "somewhat likely," "very likely," and "yes, would attend" responses on a 5-point scale: $1=$ not at all; 5 = yes, would attend.

High proportions of respondents in all three groups $(83.0 \%, 85.4 \%$, and $84.7 \%$, for part-time University of Alberta undergraduates, Grant MacEwan students, and former Arts students respectively) had access to basic computer technology such as word processing. As questions related to technology which was more recent or more sophisticated, these numbers dropped by almost half. The majority of respondents had never taken courses using technology or alternative delivery mediums. Of those who had, print-based correspondence was by far the most frequently used method. When questioned on interest in taking courses using alternative delivery methods, responses were generally low to moderate across data sets. The greatest level of interest was expressed in 




The Canadian Journal of Higher Education Volume XXX, No. 1, 2000 
computer-assisted instruction such as CD ROM, followed by computer conferencing. ${ }^{3}$ Responses on technology and alternative delivery were highly consistent across all three student groups. Figure 3 therefore averages data from all three groups on levels of interest in six different methods of distance delivery.

Finally, a short series of questions asked part-time undergraduates at the University of Alberta to indicate the advantages and disadvantages of part-time attendance. Students were asked to list up to three advantages and disadvantages. The most frequently listed advantage was that parttime status allowed time for work commitments (55.6\% of respondents). This finding is consistent with the reasons for part-time attendance for this group, and also with other data sets. Perhaps surprisingly, work commitments was followed by personal fulfillment and fit with personal lifestyle $(39.1 \%)$, and this was followed by family commitments $(16.4 \%)$. The most frequently stated disadvantage of part-time status was limited course selection including limited evening course selection $(60.4 \%$ of respondents). This finding was followed by the extended time needed for degree completion (26.9\%), and poor access to services (20.4\%).

\section{IMPLICATIONS FOR RESEARCH, POLICY, AND PRACTICE}

A need exists in higher education and in educational research in general for the translation of research results into meaningful implications for policy and concrete recommendations for improvement in institutional practice. Based on findings in the present study, and with reference to previous research, a number of implications which hold promise for new institutional research and policy decision making are suggested, not as recipes for success, but rather as guidelines for thought on how institutions can improve performance in addressing the access needs of part-time learners.

\section{Part-time Enrollments and Degrees}

Part-time to total undergraduate enrollment proportions varied widely among responding institutions in this study. Roughly half of institutions were at or above the $20 \%$ part-time enrollment mark, while $20 \%$ of respondent institutions fell below $10 \%$ in part-time to total 
undergraduate enrollments. At present, it is unclear as to exactly what such enrollment differences mean, and it would therefore be inappropriate to draw conclusions from these differences. On one hand, some universities seem to carry a much larger contingent of part-time undergraduate students than others, and this is surely influenced by any number of internal and external factors. On the other hand, these enrollment proportions may be suggestive of how an institution perceives its diverse student constituencies and its external environment, and how it has used flexible policy and practice to respond to the needs of various student groups. In defining their educational mission, institutions may well require a closer examination of the educational, social, and economic costs and benefits of part-time students.

Findings in this study indicated that the dominant organizational model for the administration of part-time degree programming was through regular academic departments. Yet, previous research suggests that this approach may not be the most effective. Thompson and Devlin (1992) make a clear distinction between part-time day students and those who opt for evening and weekend programming mainly because of work. Findings in the present study confirm this distinction. Smith and Saunders (1988) identified two models of part-time provision - full-time programs with small numbers of integrated part-time students, and freestanding or distinct part-time degree programs - and concluded that the majority of part-time students continue to be integrated into existing fulltime programs. After further examination of part-time provision models, Rickwood (1995) identified distinct programs used by ex-polytechnics in the U.K. as being more supportive and comprehensive.

What may be most significant about findings on part-time degrees and degree programming is the ambiguity inherent in data. Attempts to create a profile of part-time degree offerings at Canadian universities were hindered by a number of factors ranging from different reporting practices and a lack of knowledge and information available to those completing questionnaires, to differing conceptions of what constitutes a university degree itself. In short, more accurate knowledge and information is needed on the nature and extent of part-time degree programming offered by institutions. Such knowledge and information would be 
prerequisite to assessing how these programs perform compared to other types of programs, and could prove to be extremely useful as we move into the 21 st Century.

It appears that in the U.S. at least, postsecondary institutions have begun to respond to the needs of a more mature, nontraditional student population. In recent research based on a sample of regionally accredited, public and private, baccalaureate colleges and universities in the central U.S., it was found that (a) approximately $75 \%$ of institutions had mission statements acknowledging adult learners, (b) almost $50 \%$ had adult degree completion programs in place, (c) $87 \%$ had some form of credit-granting for prior learning, (d) $88 \%$ had alternative time frames for part-time attendance and completion, (e) $73 \%$ incorporated workplace learning, cooperative programs, or internships, (f) $62 \%$ offered courses at off-campus locations at convenient times, (g) $85 \%$ of programs allowed students to complete an entire degree outside of traditional daytime hours, and (h) only $17 \%$ used some form of technology or distance delivery (Murry \& Hall, 1998).

\section{Evening and Weekend Programming}

Additional findings in this study suggest ways in which innovative programming and course scheduling could have potential for soliciting the mature part-time student. For example, despite differences in attendance plans and expectations for degree completion, large numbers of students from all three response groups indicated that they would likely attend evening and weekend degree programming, thus, both types of offerings could serve the more mature part-time student. Yet, many more institutions continue to offer a far greater number of evening courses than weekend courses.

Based on research at the University of Victoria, Devlin (1989) suggests that scheduling and timetabling development should focus on third- and fourth-year course levels, since students tended to shift to part-time study nearer degree completion. Some support for this exists in the present study where $41 \%$ of University of Alberta part-time undergraduates were fourth-year and after-degree students. 
Thompson and Devlin (1992) state that "it is possible that the number of part-time students would be greater if there were increased availability of evening/weekend courses" (p. 66). The analysis of data from Canadian universities revealed a positive correlation $(r=.4496$; $p=.002$ ) for part-time enrollments and the extent of evening course offerings, independent of the influence of full-time enrollments. It appears that these authors were correct in their assumptions concerning a relationship between part-time numbers and alternative course scheduling. What may be needed is research which firmly establishes the "causal direction" of this relationship and which identifies other influencing variables. At the very least, increases in the extent of evening programming will most likely lead to part-time enrollment growth. This, in turn, offers institutions one proactive strategy for countering the unpredictable effects of shifting social trends such as a sudden decline in part-time attendance. Other strategies need to be identified.

\section{Students' Experiences and Student Services}

Extensive research has established that formal and informal contact with faculty and interaction with peer groups has a direct influence on undergraduate student growth and development in a number of cognitive and psychosocial areas and that this, in turn, affects retention and degree completion (Astin, 1993; Pascarella \& Terenzini, 1991). In fact, Astin (1993) goes further and suggests that "the student's peer group is the single most potent source of influence on growth and development during the undergraduate years" [italics removed] (p. 398). However, the argument being made in this paper is that in many ways, the mature part-time student constitutes a distinct nontraditional group, perhaps with a quite distinct set of educational needs. Given the profile of this group including age, gender, family backgrounds, prior education, income, and educational plans and expectations, it is likely that the impact of academic and social integration variables on educational outcomes will be quite different when compared to the traditional, 18 to 24 year-old, full-time, campus resident. For example, some research (Astin, 1993; Grayson, 1995, 1997; Tinto, 1998) suggests that social integration will play a considerably modified role in influencing student success. For the mature 
part-time student commuting to campus at night or on weekends, extensive peer interaction or out-of-class faculty interaction is surely constrained, and perhaps even non-existent. Further, it is likely that psychosocial development in areas such as attitudes, values, educational aspirations, and goals, has already occurred for many of these students. It is also likely that mature part-time commuters will spend significant time, or most of their social time, with co-workers, family members, or other non-students, and that these contacts will tend to reinforce values and attitudes which are already quite distinct from those of the traditional 18 to 24 year-old (Astin, 1993).

This profile may point to academic involvement as being of prime importance in the success of mature part-time students. If the role of social integration is reduced or nonexistent, this places the primary emphasis on what students experience, academically, in the classroom (see similar discussions in Grayson, 1995, 1997, but for younger commuting undergraduates). This classroom contact may be the only means of institutional involvement for this group of students. As Tinto (1998) aptly puts it: "If involvement or integration is to occur, it must occur there [in the classroom]... They simply do not have the luxury of having free time to spend on campus" (p. 173). The implications for the theory and practice of teaching and learning in higher education are significant. Principles of effective teaching and learning for adults in colleges and universities (Pascarella \& Terenzini, 1991) may become increasingly important and receive much needed additional attention.

These questions concern the comparative impact of academic and social integration variables on the growth and development of nontraditional students, and how this difference influences retention, persistence, and degree completion. At present, we have little in the way of answers to these questions. Therefore, a clear need exists for intensive research in this area, the results of which could have far-reaching implications for institutional policy and practice, and ultimately, profound cost implications for the delivery of programs and the provision of services.

Some recent research may already be challenging our assumptions on service provision. Noble (1989), studying part-timers at the University of Ottawa, discovered that $70 \%$ of respondents did not read 
university publications. Thirty-five percent of part-time undergraduate respondents at the University of Alberta were not on campus to access university services outside of class times (Keast \& Broadbent, 1997). A recent study at the University of Toronto suggests that flexible schedules and class times are most important for older, married, and particularly female students. Results also showed that the least important expectations for part-time students were meeting new friends and participating in university social activities (University of Toronto, Wilfred Laurier University, n.d.). The question seems to be this: To what extent will mature part-time students with family support systems, full-time jobs and perhaps benefits, relatively high family incomes, and well defined academic expectations and goals, access a wide array of services ranging from financial, health, and physical education and recreation, to counselling, part-time associations, or other social amenities? At least some service provision will be inconsistent with the needs of mature part-timers. In turn, greater awareness of these inconsistencies may translate into cost savings (or increased revenue) to both the student and the institution (for example, if part-time students are not charged for services not used, because of reduced demand from this group on various student services, or because many educational costs will remain relatively stable against part-time enrollment growth). The little research which exists on this topic suggests that the cost savings in educating a part-time student compared to a full-time student could be as high as 50\% (Rickwood, 1995).

\section{Technology and Distance Learning}

Findings in the present study indicated that interest in technology and the alternative delivery of courses for three groups of on-campus undergraduates was, at best, "lukewarm." What may be most significant about these findings is the high degree of consistency in patterns of responses across the three data sets in which the variables were examined. This result raises questions as to whether the findings in this study on access to technology, an understanding of its functioning, and most important, interest in its educational use, are not, perhaps, a more widespread phenomenon. Previous research on part-time students and distance education tends to reinforce this question. Thompson and Devlin (1992) state that 
"there is substantial evidence, ...that distance education programs are not as attractive to many part-time students as regular classroom instruction" (p. 68). Broomfield (1993) also suggests that distance learning can be an unsatisfactory alternative for many part-timers (p. 202).

Yet, technology and distance education and its impact on the future of higher education remains a topic of heated debate. Many in postsecondary education believe that the emerging educational technologies and the options for teaching and learning that they provide hold out great promise for expanded access to postsecondary opportunities, increased responsiveness to learning needs, expanded options for students' control of their own learning, and cost effectiveness in the delivery of programs and services. In fact, the new learning technologies may be challenging our conventional notions of student and faculty roles, as well as the way in which students and faculty will interact in the future (Pascarella \& Terenzini, 1998). And as the population of parttime, adult, and lifelong learners increases, so too will the demand for more accessible and flexible programming, including an increased demand for technology-based learning.

Although the direct link between faculty-student and student-student interaction and various types of cognitive and psychosocial development has been well documented for full-time, on-campus undergraduates (Astin, 1993; Pascarella \& Terenzini, 1991), the relation between various forms of interaction and student growth is not well understood within the context of distance education. ${ }^{4}$ Moreover, the typical emphasis in most universities to date has been on the use of educational technologies for direct course development and delivery, with little attention paid to the distinction between direct instructional use and learning support use. Analyses of patterns of attendance and the needs of mature part-timers (Keast \& Broadbent, 1997) and discussions of the future value of educational technology and learning communities (Pascarella \& Terenzini, 1998; Tinto, 1998) suggest that new educational technologies hold potential for playing an innovative role as a surrogate for face-to-face social involvement; that is, as an alternative means for enhancing social integration. For example, the establishment of small, cohort-based, "virtual" learning communities may provide a new avenue for social cohesion and 
support for mature part-timers which, because of their work and family responsibilities and socioeconomic circumstances, is typically lacking. The extent to which new learning technologies might play a valuable social as well as academic involvement role in the growth and development of these students remains relatively unexplored territory, both in distance education research and in college impact research.

\section{CONCLUSION}

Based on the findings and implications described here, can anything more general be said about institutional research and policy change? A few final points are worth noting. First, the case which can be made for how demographic trends alone will impact educational policy is quite straightforward. Our student population will most likely continue to age. At the present time, the dominant cohort in the Canadian population is the 30 to 39 year-old age group. In 1996, the median age was 35.1 years; by 2006 it is estimated to be 38.4 years (Statistics Canada, 1994). Recent analyses of national data in the U.S. show a growing diversity and ethnocultural mix in the undergraduate student population (Astin, 1998), as well as a marked increase in the number of undergraduates attending on a part-time basis (Pascarella \& Terenzini, 1998). Somewhat more alarming are increases, both in Canada and the U.S., in the number of undergraduates who depend on employment to pay for their education (see Pascarella \& Terenzini, 1998 for U.S. data; and Etcheverry, Clifton, \& Roberts, 1993; Johnson, 1994; and Keast \& Broadbent, 1997, for employment numbers for different student groups at two Canadian universities). Furthermore, increases in female participation in postsecondary education over the last few decades have been well documented in the Canadian literature (see discussions in earlier sections of this paper), and recent U.S. data (Astin, 1998), also show women attending college and university in ever-increasing numbers. In the present study, two-thirds of participants in three separate respondent groups (including part-time and full-time) were female. Taken together, these trends, combined with the need for continual skills upgrading and lifelong learning, will most surely have profound implications for how educational policy needs to be formulated in the future. 
Second, the advent of these demographic trends exposes a need for student-centred and program-relevant knowledge and information on the basis of which policy decisions can effectively proceed. Although a good deal of research already exists in the U.S. and elsewhere (see for example Pascarella \& Terenzini, 1991; and Bourner et al. 1991), Canada appears to be in its infancy in establishing an adequate understanding of these complex relations. To date, attempts have been noteworthy, but research has been conducted by a small handful of scholars, initiatives are isolated and therefore fragmented, without the benefit of conceptual schemes which could "pull together" findings and implications on a number of fronts. As a result, we do not yet know enough about the effects of postsecondary education on students' cognitive growth or on various psychosocial changes and the development of attitudes and values. We do not know enough about the variables which influence attrition, persistence, and degree completion, or about how educational attainment contributes to later social and economic status. Nor do we have the requisite data available to compare the effects of different kinds of institutions on students, or to generalize about whether various postsecondary experiences (within and between institutions) affect different groups of students differently. Most important for this discussion, there is a need for much more extensive study of the nontraditional student (Pascarella \& Terenzini, 1991, 1998; Terenzini, 1996). Compared to fulltime undergraduates, a great deal less is known about the effects of institutional variables on learners who must balance work, family, and educational responsibilities, and whose purposes for attending university may be quite different from the younger full-time student.

A final point relates to the value of relevant knowledge and information for policy decision making, and to how this knowledge and information is used. In the last few decades, educational institutions have invested considerable resources in strategic planning efforts intended to define, establish, or reaffirm educational missions and values. Typically, however, these initiatives are "top-down" sorts of activities, where decision making proceeds from public policy on education, through major institutional stakeholders, and down to various student clienteles. Thus, students remain situated at the receiving end of the implementation of 
what policy makers decide "ought" to be done. In contrast, it is suggested that the research described here serves as a good example of an alternative "bottom-up" approach, where, potentially, the process moves from relevant knowledge and information on students and programs to institutional change; that is, from student needs to institutional responses. This paradigm depicts a quite different institutional policy decision model. The essential difference lies in the "directional flow" of the process itself, and therefore in the type and quality of knowledge on which decisions are based. Future access to higher education for the growing numbers of nontraditional students would then depend on how institutions chose to use this knowledge to improve educational practice.

\section{Notes}

1 Discussions in this section were adapted from a research report which provides more detail on findings within each data set. Readers are encouraged to consult Keast, D., \& Broadbent, R. (1997). Access to Part-Time University Studies. Edmonton, AB: University of Alberta, Special Sessions Office.

2 Wide standard deviations here are the result of one or two institutions offering a very large number of evening and weekend courses compared to others. For example, the number of evening courses offered by responding institutions ranged from 2 to 1140 , with a median of 138 courses.

3 Questions on technology and alternative delivery were supplied courtesy of Dr. Terry Anderson, Director, Academic Technologies for Learning (ATL), University of Alberta

4 On one hand, a substanital body of distance education research on delivery methods, levels of interaction, and student achievement shows "no significant difference" in student learning when compared to conventional classroom instruciton methods. (See Russell, 1992, Television's indelible impact on distance education: What we should have learned from comparative research, Research in Distance Education, 4(4), for an introduction to this literature.) However, it is fair to suggest that fundamental differences exist in how interaction variables are defined and examined in a distance education context compared to measurements in conventional classroom settings. 


\section{References}

Altbach, P.G. (1998). Students: A changing constituency at the heart of the academic enterprise. The Review of Higher Education, 21(2), 111-113.

Anisef, P. (1989). Studying part-time in Canada's universities: A social change perspective. The Canadian Journal of Higher Education, 19(1), 11-28.

Ashar, H., \& Skenes, R. (1993). Can Tinto's student departure model be applied to nontraditional students? Adult Education Quarterly, 43(2), 90-100.

Association of Part-time Undergraduate Students. (1991). Survey of parttime undergraduate students at the University of Toronto. Toronto, ON: Author.

Association of Universities and Colleges of Canada. (1994). Preliminary enrolment data Canada, Fall 1994. Unpublished raw data.

Association of Universities and Colleges of Canada. (1996a). Preliminary university enrolment, 1996 - final university enrolment, 1995. Unpublished raw data.

Association of Universities and Colleges of Canada. (1996b). Trends 1996: The Canadian university in profile. Ottawa, ON: Author.

Astin, A.W. (1993). What matters in college? Four critical years revisited. San Francisco, CA: Jossey-Bass.

Astin, A.W. (1998). The changing American college student: Thirty-year trends, 1966-1996. The Review of Higher Education, 21(2), 115-135.

Bauer, W.K. (1981). Strategies for recruiting and retaining the nontraditional student. College Student Journal, 15(3), 234-238.

Belanger, R., Lynd, D., \& Mouelhi, M. (1982). Part-time degree students: Tomorrow's majority? Ottawa, ON: Minister of Supply and Services Canada.

Bourner, T., Reynolds, A., Hamed, M., \& Barnett, R. (1991). Part-time students and their experience of higher education. Buckingham: SRHE and Open University Press.

Broomfield, C. (1993). The importance of mature, part-time students to higher education in the U.K. Higher Education, 25, 189-205.

Canadian Education Statistics Council. (1996). Education indicators in Canada. Toronto, ON: Author.

Canadian Organization of Part-time University Students. (1987). Part-time university students in Canada: An analysis of the 1974-75 and 1983-84 postsecondary student surveys. Prepared by P. Anisef, North York, ON: York University.

Change Magazine. (1986, July-August). Part-timers: Myths and realities. Change, 18(4), 49-53. 
Clifton, R.A. (1997). The effects of social psychological variables and gender on the grade point averages and educational expectations of university students: A case study. The Canadian Journal of Higher Education, 27(2,3), 67-90.

Darkenwald, G., \& Gavin, W. (1987). Dropout as a function of discrepancies between expectations and actual experiences of the classroom social environment. Adult Education Quarterly, 37(3), 152-163.

Department of the Secretary of State of Canada. (1989). Profile of Higher Education in Canada - 1988-1989. Ottawa, ON: Minister of Supply and Services Canada.

Department of the Secretary of State of Canada. (1990). Profile of Higher Education in Canada - 1990 Edition. Ottawa, ON: Minister of Supply and Services Canada.

Department of the Secretary of State of Canada. (1992). Profile of Higher Education in Canada - 1991 Edition. Ottawa, ON: Minister of Supply and Services Canada.

Devlin, L. (1989). Part-time students: A closer look. Canadian Journal of University Continuing Education, 15(1), 29-38.

Etcheverry, E., Clifton, R., \& Roberts, L. (1993). Time use and educational attainment: A study of undergraduate students. The Canadian Journal of Higher Education, 23(3), 1-7.

Gibson, C., \& Graff, A. (1992). Impact of adults'preferred learning styles and perception of barriers on completion of external baccalaureate degree programs. Journal of Distance Education, 7(1), 39-51.

Grayson, J.P. (1995). Does race matter? Outcomes of the first year experience in a Canadian university. The Canadian Journal of Higher Education, 25(2), 79-109.

Grayson, J.P. (1997). Place of residence, student involvement, and first year marks. The Canadian Journal of Higher Education, 27(1), 1-23.

Grosset, J.M. (1991). Patterns of integration, commitment, and student characteristics and retention among younger and older students. Research in Higher Education, 32(2), 159-178.

Holdaway, E. \& Kelloway, K. (1987). First year at university: Perceptions and experiences of students. The Canadian Journal of Higher Education, 17(1), 47-63.

Human Resources Development Canada. (1994). Profile of Postsecondary Education in Canada - 1993 Edition. Prepared by L. Nobert \& R. McDowell. Ottawa, ON: Minister of Supply and Services Canada. 
Johnson, G.M. (1994). Undergraduate student attrition: A comparison of the characteristics of students who withdraw and students who persist. Alberta Journal of Educational Research, 15(3), 337-353.

Keast, D. (1998). Part-time university education. International Journal of Educational Management, 12(3), 114-119.

Keast, D., \& Broadbent, R. (1997). Access to part-time university studies: An examination of undergraduate programs and student populations with potential for part-time degree completion. Edmonton, AB: University of Alberta, Special Sessions Office.

Memorial University of Newfoundland. (1995). A study of the decline in part-time undergraduate enrollment (CIAP Report 95-02). St. John's: Centre for Institutional Analysis and Planning.

Morris, J., \& Potter, J. (1996). Continuing education policies and practices in Canadian universities: An overview. Ottawa, ON: Canadian Association for University Continuing Education.

Murry, J., \& Hall, B. (1998, Spring). A systematic approach to designing and evaluating effective adult degree completion programs. The Journal of Continuing Higher Education, 19-26.

Noble, K. (1989). What a marketing survey of part-time university students reveals about barriers to learning. Open Learning, 4(2), 16-20.

O'Brien, E.M. (1992). Part-time enrollment: Trends and issues. Research Briefs, 3(8). Washington, DC: Division of Policy Analysis and Research, American Council on Education.

Pascarella, E., \& Terenzini, P. (1991). How college affects students. San Francisco, CA: Jossey-Bass.

Pascarella, E., \& Terenzini, P. (1998). Studying college students in the 21 st century: Meeting new challenges. The Review of Higher Education, 21(2), 151-165.

Rickwood, P. (1995). Others like us? - A study of part-time degree provision outside the Open University. Open Learning, 10(3), 16-24.

Roche, J., Shale, D., \& Kelley, W. (1996). Comparative studies on the differentiated nature of part-time students. Paper presented to the Association for Institutional Research, Annual Forum, Albuquerque, NM.

Smith, D.M., \& Saunders, M.R. (1988). Part-time higher education: Prospects and practices. Higher Education Review, 20(3), 7-22.

Stage, F.K. (1989). Reciprocal effects between the academic and social integration of college students. Research in Higher Education, 30(5), 517-530.

Statistics Canada. (1994). Population projections for Canada, provinces, and territories 1993-2016 (Cat. 91-520 Occasional). Ottawa, ON: Author. 
Terenzini, P. (1996). Rediscovering roots: Public policy and higher education research. The Review of Higher Education, 20(1), 5-13.

Thompson, G., \& Devlin, L. (1992). Access by part-time students: A question of openness in Canadian universities. The Canadian Journal of Higher Education, 22(3), 57-75.

Tight, M. (1986). The provision of part-time first degree courses in the United Kingdom. Studies in Higher Education, 11(2), 173-188.

Tight, M. (1991). Part-time higher education in western developed countries. European Journal of Education, 26(1), 63-85.

Tinto, V. (1998). Colleges as communities: Taking research on student persistence seriously. The Review of Higher Education, 21(2), 167-177.

University of Alberta. (1984). Characteristics of part-time undergraduate students 1983 (Project No. 82.24). Edmonton, AB: Office of Institutional Research and Planning.

University of Alberta. (1996). Summary of statistics, 1995-96. Edmonton, AB: Office of the Registrar and Student Awards.

University of Alberta. (1997). Summary of statistics, 1996-97. Edmonton, AB: Office of the Registrar and Student Awards

Wilfrid Laurier University \& Woodsworth College, University of Toronto. (n.d.). PSS: Part-time student study. Toronto, ON: Authors.

Wolfe, J.S. (1993). Institutional integration, academic success, and persistence of first-year commuter and residence students. Journal of College Student Development, 34(5), 321-326. 